\title{
Article/Artigo
}

\section{Seroepidemiological monitoring in sentinel animals and vectors as part of arbovirus surveillance in the State of Mato Grosso do Sul, Brazil}

\author{
Monitoramento soroepidemiológico em animais-sentinela e vetores como parte da vigilância \\ de arbovírus, no Estado de Mato Grosso do Sul, Brasil
}

\section{Paulo Mira Batista ${ }^{1,2}$, Renato Andreotti ${ }^{1,3}$, Jannifer Oliveira Chiang ${ }^{4}$, Milene Silveira Ferreira ${ }^{4}$ and Pedro Fernando da Costa Vasconcelos ${ }^{4}$}

\section{ABSTRACT}

Introduction: From February-September 2010, seroepidemiological surveys were conducted on non-human primates and transmitter vector capture was used to investigate the possible circulation of arboviruses in the municipalities of Bonito, Campo Grande, and Jardim, State of Mato Grosso do Sul, Brazil. Methods: A total of 65 primates from the wild and captivity were used, and potential vectors were captured using Castro and dip nets. Serum samples were tested at the Instituto Evandro Chagas, State of Pará, using the hemagglutination inhibition test to detect total antibodies against 19 different arboviruses. Virus isolation was attempted from serum samples and arthropod suspensions using newborn mice and the $\mathrm{C} 6 / 36$ cell line clone. In addition, identification of the vector species was conducted. Results: From the 19 serum samples from Campo Grande, 1 sample had a 1:20 titer for Flavivirus. From the 35 samples collected in Bonito, 17 samples had antibodies to arboviruses, 4 (11.4\%) were positive for Alphavirus, and $5(14.2 \%)$ were positive for Flavivirus. Monotypic reactions were observed for the Mayaro $(\mathrm{n}=10)$ and Oropouche $(\mathrm{n}=5)$ viruses, and $6(17.1 \%)$ samples had titers for $>1$ virus. We captured 120 Culicidae individuals that were potential arbovirus transmitters in Jardim; however, all the samples were negative for the viruses. Conclusions: Mato Grosso do Sul has a variety of vertebrate hosts and transmission vectors, thereby providing ideal conditions for the emergence or reemergence of arboviruses, including some pathogenic to human beings.

Keywords: Non-human primates. Vectors. Arboviruses.

\section{RESUMO}

Introdução: No período de fevereiro a setembro de 2010, foram realizados inquéritos soroepidemiológicos em primatas não humanos e captura de vetores transmissores, com o intuito de investigar a possível circulação de arbovírus nos municípios de Bonito, Campo Grande e Jardim, no Estado do Mato Grosso do Sul, Brasil. Métodos: Foram utilizados 65 primatas de vida livre e de cativeiro, e potenciais vetores capturados por Castro e puçás. As amostras séricas foram testadas pelo teste de inibição da hemaglutinação para a detecção de anticorpos totais contra 19 diferentes arbovírus e a tentativa de isolamento viral (camundongo recém-nascido e linhagem celular-clone $\mathrm{C6/36)}$ nas amostras séricas e suspensões de artrópodes, bem como a identificação das espécies vetoriais foram realizadas no Instituto Evandro Chagas-IEC no Estado do Pará. Resultados: Das 19 amostras séricas do município de Campo Grande, 1 apresentou titulo de 1:20 para Flavivirus. Das 35 amostras coletadas em Bonito, 17 apresentaram anticorpos para arbovírus, sendo $4(11,4 \%)$ positivos para Alphavirus, e $5(14,2 \%)$ positivos para Flavivirus. Reações monotipicas foram observados para o vírus Mayaro $(n=10)$ e para o vírus Oropouche $(n=5)$ e $6(17,1 \%)$ amostras apresentaram títulos para mais de um dos vírus estudados. Foram capturados 120 Culicídeos potenciais transmissores de arbovírus no município de Jardim. Todas as amostras coletadas foram negativas para o isolamento viral. Conclusões: Por possuir uma variedade de hospedeiros vertebrados e vetores transmissores, o Mato Grosso do Sul apresenta condições propícias para a emergência ou reemergência de arbovírus, inclusive alguns patogênicos para os seres homem.

Palavras-chaves: Primatas não humanos. Vetores. Arboviroses.

1. Programa de Pós-Graduação em Doenças Infecciosas e Parasitárias, Universidade Federal de Mato Grosso do Sul, Campo Grande, MS. 2. Coordenadoria Estadual de Vigilância Epidemiológica, Secretaria de Estado de Saúde, Campo Grande, MS. 3. Empresa Brasileira de Pesquisa Agropecuária, EMBRAPA Gado de Corte, Campo Grande, MS. 4. Seção de Arbovirologia e Febres Hemorrágicas, Instituto Evandro Chagas, Secretaria de Vigilância em Saúde, Ananindeua, PA.

Address to: Dr. Paulo Mira Batista. Coordenadoria Estadual de Vigilância Epidemiológica/SES/MS. Av. do Poeta, Bloco 7, Jardim Veraneio, Parque dos Poderes, 79031-902 Campo Grande, MS, Brasil.

Phone: 5567 3318-1682; Fax: 5567 3318-1682

e-mail: paulo.mira@uol.com.br

Received in 11/04/2011

Accepted in 30/09/2011

\section{INTRODUCTION}

Arboviruses are almost completely maintained in the natural environment; consequently, people who have contact with enzootic foci are most at risk of acquiring infections that represent a public health problem ${ }^{1}$. Arboviruses are classified into 5 families according to their antigenic properties: Bunyaviridae, Flaviviridae, Reoviridae, Rhabdoviridae, and Togaviridae. In Brazil, some arboviruses have appeared regularly in urban areas (e.g., dengue virus [DENV] and Oropouche virus [OROV]) or in peri-urban areas (e.g., Mayaro virus [MAYV] and yellow fever virus [YFV]) as epidemics by infecting susceptible communities and causing febrile rash illness and/or hemorrhagic fevers or central nervous system diseases and meningitis, as is the case for Saint Louis encephalitis virus (SLEV), Rocio virus (ROCV), eastern equine encephalitis virus and western equine encephalitis virus ${ }^{1,2}$.

Studies on arboviruses involve virology, serology, entomology, ecology, and zoology ${ }^{3}$. Because they are usually diurnal arboreal species, non-human primates are more often infected by an arbovirus than other terrestrial animals; however, most of them have low hemagglutination inhibition antibody titers ${ }^{4}$. Interactions between humans and non-human primates that live in tropical forests are increasingly seen due to the development of ecotourism, subsequently increasing the risk of viral transmission. Non-human primates can act as important hosts in the cycle of several zoonoses, and as they belong in a habitat with high biodiversity, they serve as natural sentinels in the surveillance of several emerging viruses. It is common to use sentinel animals in arbovirus seroepidemiological studies as this represents a feasible method to obtain information about the circulation of these viruses in the natural environment ${ }^{5,6}$.

Serological studies on free-living or captive animals can determine antibody seropositivity rates, which often can lead to an understanding of virus circulation dynamics and host susceptibility; 
however, susceptibility may be speculated upon even if the agent has not been isolated ${ }^{4}$.

It is extremely important to study this relationship, considering the direct or indirect participation of non-human primates in maintaining the epidemiological cycles of several arboviruses and that some of these viruses are responsible for diseases that range from asymptomatic cases to hemorrhagic fevers with a high mortality rate.

\section{METHODS}

A total of 65 non-human primates were used in the study (2 Alouatta caraya, 1 Callicebus donacophilus, and 62 Cebus apella). Of these, 28 (43.1\%) were female and 37 (56.9\%) were male; 11 (16.9\%) were captured in Jardim municipality, 35 (53.9\%) in Bonito municipality, and 19 (29.2\%) were from the colony at the Center for the Rehabilitation of Wild Animals (CRAS) (Table 1), located in Campo Grande (Figure 1), State of Mato Grosso do Sul, during February-October 2010.

In these municipalities, the ecosystem is predominated by cerrado, which consists of bushy, small, bent, and twisted trunk trees. The cerrado has well-defined seasons, i.e., a rainy summer
TABLE 1 - Distribution of the species and sex of free-ranging and captive non-human primates captured from February-October 2010 in Bonito, Campo Grande, and Jardim municipalities in the State of Mato Grosso do Sul, Brazil.

\begin{tabular}{lccccccc}
\hline & \multicolumn{2}{c}{ Municipality } & \multicolumn{2}{c}{ Sex } \\
Primate species & Bonito & Jardim & Campo Grande & females & males & Total \\
\hline Allouata caraya & - & - & 02 & 0 & 2 & 2 \\
\hline Callicebus donacophilus & - & - & 1 & 0 & 1 & 1 \\
\hline Cebus apella & 35 & 11 & 16 & 28 & 34 & 62 \\
\hline
\end{tabular}

season, which occurs from October to April, and a dry winter season, which extends from June to August.

The City of Campo Grande, the capital of Mato Grosso do Sul, is located in the central region, with an elevation of $\sim 532 \mathrm{~m}$ above sea level $\left(20^{\circ} 26^{\prime} 34^{\prime \prime} \mathrm{S}\right.$ and $\left.54^{\circ} 38^{\prime} 47^{\prime \prime} \mathrm{W}\right)$. It has an estimated area of $8,096.05 \mathrm{~km}^{2}$, with a population of $\sim 765,000$ inhabitants. CRAS is located in an urban area of Park Estadual do Prosa. The park has an approximate area of $1,35 \mathrm{~km}^{2}$ in Serra de Maracaju Plateau, and it has enclosures for birds, mammals, and reptiles. The non-human primates are housed according to their biological characteristics in collective places and they are fed on fruits, seeds, and vegetables, while the carnivores are fed with live prey in order to encourage them to follow their intuitive hunting practices.

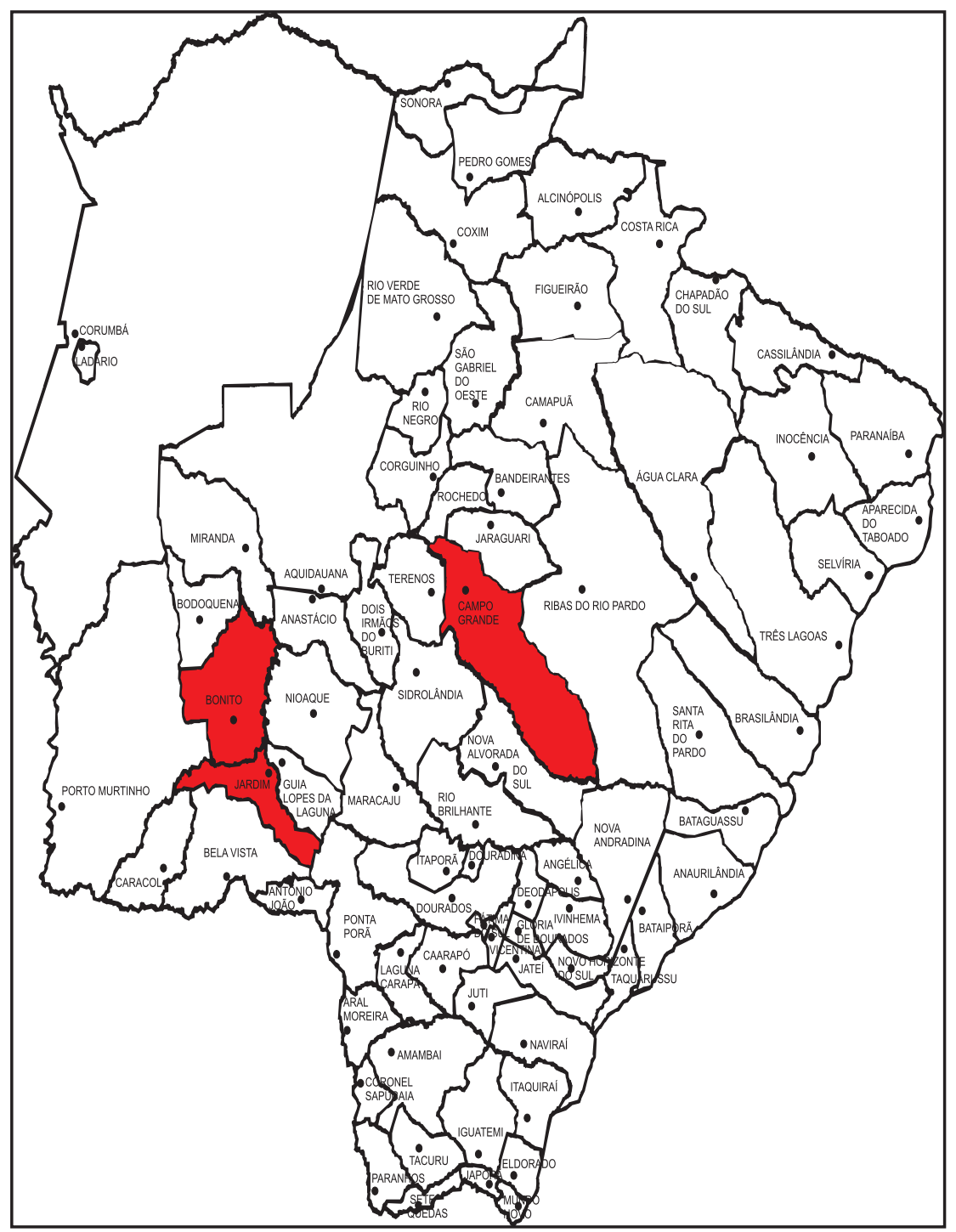

FIGURE 1 - Map of the State of Mato Grosso do Sul. The municipalities where the seroepidemiological non-human primate surveys were conducted are highlighted. 
Jardim municipality is located in the southwest of the state $\left(21^{\circ} 28^{\prime} 49^{\prime \prime} \mathrm{S}\right.$ and $\left.56^{\circ} 08^{\prime} 17^{\prime \prime} \mathrm{W}\right)$. It has a territorial extension of $2,207.6 \mathrm{~km}^{2}$, with a humid subtropical climate and temperatures of $15-39^{\circ} \mathrm{C}$ (Figure 1). The City of Bonito is located in Serra da Bodoquena in the southwest of the state; it is $\sim 315 \mathrm{~m}$ above sea level $\left(21^{\circ} 07^{\prime} 16^{\prime \prime} \mathrm{S}\right.$ and $\left.56^{\circ} 28^{\prime} 55^{\prime \prime} \mathrm{W}\right)$ and has a population of $\sim 25,000$ inhabitants. The city is known worldwide for its caves, rivers, resorts, and ponds of clear water.

The animals were trapped using terrestrial Tomahawk traps, armed in a predetermined area, and easily visualized ${ }^{7}$. The animals were anesthetized using tiletamine hydrochloride and zolazepam hydrochloride $(4.4 \mathrm{mg} / \mathrm{kg})$, with the aid of dip nets, zest leather gloves, and $1 \mathrm{~mL}$ syringes. The dose was adapted to the animal's weight and it was administered intramuscularly ${ }^{8}$. We collected 3-5mL of blood from sedated animals with a weight of up to $3 \mathrm{~kg}$ and $6-10 \mathrm{~mL}$ from animals with a weight of over $3 \mathrm{~kg}$, by puncturing the femoral vein or brachial artery.

Later, the collected blood was centrifuged at $1,000 \mathrm{rpm}$ for 10 min to obtain serum. Serum aliquots and whole blood samples were placed in cryovials. The samples were frozen in liquid nitrogen and stored at $-70^{\circ} \mathrm{C}$ until processing ${ }^{9}$. Biometric data as well as data pertaining to body temperature and heart and respiratory rate were collected (data not reported). For future studies, microchips (transponders) for identification were implanted in the subcutaneous interscapular region, with later confirmation using a specific reader. Until they recovered completely from the anesthesia, the animals were kept in appropriate cages, covered with canvas, and kept away from sources of stress. After recovery from the anesthesia, the animals were released.

The transmitter vectors were captured over 3 days, from 09:00 to $15: 00$. The captured Culicidae specimens were placed in 5-mL cryovials, frozen in liquid nitrogen, and stored at $-70^{\circ} \mathrm{C}$ until vector identification and virus isolation.

The 65 serum samples collected from non-human primates were tested using hemagglutination inhibition (HI) against 19 different types of arboviruses, including the following genera: Alphavirus (eastern equine encephalitis, western equine encephalitis, Mayaro, and Mucambo viruses), Flavivirus (yellow fever, Ilheus, St. Louis encephalitis, Cacipacoré, Rocio, and Bussuquara viruses) Orthobunyavirus (Guaroa, Maguari, Tacaiuma, Utinga, Belém, Caraparu, Oropouche, and Catu viruses), and Phlebovirus (Icoaraci virus) ${ }^{1}$.

For virus isolation, newborn mice (Mus musculus) were inoculated intracerebrally with $0.02 \mu \mathrm{L}$ serum and blood isolated from the non-human primates, which were diluted in $1.8 \mathrm{~mL}$ penistrep $(100 \mathrm{UI} / \mathrm{mL}$ penicillin and $100 \mu \mathrm{g} / \mathrm{mL}$ streptomycin $)$. The animals were observed daily for 21 days and no changes were noted on their identification cards. Concomitantly, $40 \mu \mathrm{L}$ of blood and serum from the studied animals (diluted 1:10 in culture medium) were added to different culture flasks that contained an Aedes albopictus cell line (clone C6/36) and Leibnitz culture medium modified with L-glutamine (L-15) plus tryptose, nonessential amino acids, penicillin $(100 \mathrm{UI} / \mathrm{mL})$, streptomycin $(100 \mu \mathrm{g} / \mathrm{mL})$, and fetal bovine serum ( $5 \%$ for growth and $2 \%$ for maintenance). Flasks containing confluent cell monolayers were observed daily for 10 days by using an inverted optical microscope for cytopathic effect verification (CPe). Similarly, after filtering, the arthropod vector suspensions were inoculated at a ratio of 1:10 in culture medium.
When observing the $\mathrm{CPe}$, the presence of the virus in the studied samples was confirmed using indirect immunofluorescence ${ }^{10}$ with polyclonal Alphavirus and Flavivirus ${ }^{1}$ antibodies.

The information obtained was stored in a database using Microsoft Excel (2007).

\section{Ethical considerations}

This study was approved by the Ethics Committee on Animal Use of the Federal University of Mato Grosso do Sul (no. 251/2010), IBAMA (n 21,808-1), and the Institute of Environment of Mato Grosso (no. 23/108,891/2009). In addition, this study had technical, logistical, and administrative support, and permanent and consumable materials provided by the State Secretariat of Health of Mato Grosso do Sul. The animal capture and identification techniques were designed to be less invasive in order to preserve the welfare of the animals and to relieve potential stress.

\section{RESULTS}

The 11 serum samples collected from non-human primates captured in the town of Jardim and tested using the HI test were negative for the virus. From the 19 serum samples collected from the CRAS non-human primate colony, 1 Cebus primate had titers of 1:20 for Flavivirus. From the 35 serum samples collected in Bonito, 17 (48.5\%) showed evidence of antibodies for arboviruses, with 4 (11.4\%) positive for Alphavirus and 5 (14.2\%) positive for Flavivirus. Monotypic reactions were observed for MAYV $(\mathrm{n}=10)$ and OROV $(\mathrm{n}=5)$ (Table 2). Six (17.1\%) samples showed positive results for $>1$ arbovirus (Table 3 ).

All samples studied yielded negative results for the presence of the viruses in newborn mice and C6/36 cell culture. We captured 120 competent vector species that were associated with the transmission of Alphavirus, Flavivirus, and Orthobunyavirus (Table 4).

TABLE 2 - Titer results for the arboviruses, using the hemagglutination inhibition test, isolated from free-ranging and captive non-human primates captured from February-October 2010 in Bonito, Campo Grande, and Jardim municipalities in the State of Mato Grosso do Sul, Brazil.

\begin{tabular}{|c|c|c|c|c|c|c|c|c|c|c|}
\hline \multirow{3}{*}{$\begin{array}{l}\text { HI* Results }^{*} \\
\text { (antibody titer) }\end{array}$} & \multicolumn{8}{|c|}{ Virus } & & \\
\hline & \multicolumn{2}{|c|}{ Alphavirus } & \multicolumn{2}{|c|}{ Flavivirus } & \multicolumn{2}{|c|}{ Mayaro } & \multicolumn{2}{|c|}{ Oropouche } & \multicolumn{2}{|c|}{ Total } \\
\hline & $\mathbf{n}$ & $\%$ & $\mathbf{n}$ & $\%$ & $\mathbf{n}$ & $\%$ & $\mathbf{n}$ & $\%$ & $\mathbf{n}$ & $\%$ \\
\hline 20 & - & - & 1 & 1.5 & - & - & 1 & 1.5 & 2 & 3.0 \\
\hline 40 & - & - & - & - & - & - & 1 & 1.5 & 1 & 1.5 \\
\hline 80 & - & - & - & - & 2 & 3.0 & 2 & 3.0 & 4 & 6.0 \\
\hline 160 & - & - & - & - & 7 & 10.7 & 1 & 1.5 & 8 & 12.3 \\
\hline 320 & - & - & - & - & - & - & - & - & - & - \\
\hline 640 & - & - & - & - & 1 & 1.5 & - & - & 1 & 1.5 \\
\hline 1280 & - & - & - & - & - & - & - & - & - & - \\
\hline $40-80$ & 1 & 1.5 & - & - & - & - & - & - & 1 & 1.5 \\
\hline $40-160$ & - & - & 1 & 1.5 & - & - & - & - & 1 & 1.5 \\
\hline $40-320$ & 2 & 3.0 & - & - & - & - & - & - & 2 & 3.0 \\
\hline $40-640$ & 1 & 1.5 & - & - & - & - & - & - & 1 & 1.5 \\
\hline $80-320$ & - & - & 1 & 1.5 & - & - & - & - & 1 & 1.5 \\
\hline $80-640$ & - & - & 1 & 1.5 & - & - & - & - & 1 & 1.5 \\
\hline 320 to $\geq 1,280$ & - & - & 1 & 1.5 & - & - & - & - & 1 & 1.5 \\
\hline
\end{tabular}

*hemagglutination inhibition (HI) test results: positive if $\mathrm{HI} \geq 20$. 
TABLE 3 - Serum titer of 6 free-ranging non-human primates harboring more than 1 arbovirus captured from February-October 2010 in Bonito, State of Mato Grosso do Sul, Brazil.

\begin{tabular}{lcccc}
\hline Samples/reactions* & $\begin{array}{c}\text { Alphavirus } \\
\text { titer }\end{array}$ & $\begin{array}{c}\text { Flavivirus } \\
\text { titer }\end{array}$ & $\begin{array}{c}\text { Mayaro } \\
\text { titer }\end{array}$ & $\begin{array}{c}\text { Oropouche } \\
\text { titer }\end{array}$ \\
\hline 1 (Alphavirus/Oropouche) & $40-320$ & - & - & 80 \\
\hline 1 (Alphavivus/Oropouche) & $40-320$ & - & - & 20 \\
\hline 1 (Alphavirus/Flavivirus) & $40-80$ & $40-160$ & - & - \\
\hline 1 (Flavivirus/Mayaro) & - & $320-1,280$ & 160 & - \\
\hline 1 (Mayaro/Oropouche) & - & - & 80 & 40 \\
\hline 1 (Mayaro/Oropouche) & - & - & 160 & 160 \\
\hline *Type of reaction that occurred. & & &
\end{tabular}

TABLE 4 - Diversity and abundance of potential arbovirus transmitter vector species captured in the wild during February-October 2010 in Jardim, State of Mato Grosso do Sul, Brazil.

\begin{tabular}{lrr}
\hline & \multicolumn{2}{c}{ Distribution (120) } \\
\cline { 2 - 3 } Species & $\mathbf{n}$ & $\mathbf{\%}$ \\
\hline Aedes scapularis & 11 & 9.1 \\
\hline Aedes serratus & 48 & 40.0 \\
\hline Culex species & 8 & 6.6 \\
\hline Haemagogus leucocelaenus & 11 & 9.1 \\
\hline Psorophora ferox & 9 & 7.5 \\
\hline Sabethes albiprivus & 4 & 3.3 \\
\hline Sabethes belisarioi & 3 & 2.5 \\
\hline Sabethes chloropterus & 1 & 0.8 \\
\hline Sabethes glaucodaemon & 3 & 2.5 \\
\hline Sabethes intermedius & 24 & 20.0 \\
\hline Total & $\mathbf{1 2 0}$ & $\mathbf{1 0 0 . 0}$ \\
\hline
\end{tabular}

\section{DISCUSSION}

Many serological studies on free-living animals are limited to transversal seroepidemiologic surveys ${ }^{4}$. With the $\mathrm{HI}$ test, it is possible to compare the serological results of 2 samples and detect cases of recent infection with arboviruses, when the second sample has antibody titers that are 4-fold higher than the first. This test is widely used in serological surveys since it can detect antibodies to arboviruses for a long period after natural infection. It is considered a high sensitivity and low specificity test when compared to other tests such as the capture ELISA immunoglobulin M (IgM) antibodies, which is considered the gold standard ${ }^{1}$.

In the $\mathrm{HI}$ test, it is common to observe cross-reactivity among viruses belonging to different genera. Saint Louis encephalitis virus, West Nile Virus (WNV), and ROCV form an antigenic complex with Japanese encephalitis virus, which complicates the interpretation of $\mathrm{HI}$ test results, making it necessary to carry out more specific tests. Thus, $\mathrm{HI}$ test results should be cautiously interpreted, especially when the investigated samples come from endemic areas where different arboviruses commonly co-circulate ${ }^{11,12}$.

We found cross-reactivity among viruses belonging to the Flavivirus genus in 5 serum samples, which precluded the identification of the infecting virus and the infection time. Positive results for antibodies against Flavivirus suggest that the host has been previously exposed to some of the arboviruses studied and produced antibodies against them ${ }^{4}$. Due to the presence of cross-immune protection, it is possible that some arboviruses remain silent in Brazil.
The negative results found in the virus isolation and cell culture experiments of this study are consistent with those found in a study of 35 non-human primates in San Pedro, located in the central region of Paraguay, which sought to isolate YFV using the E6 Vero cell line ${ }^{13}$.

For the inoculation of newborn mice and for reverse transcription polymerase chain reaction (RT-PCR), personnel at the Instituto Evandro Chagas isolated YFV from the blood and viscera samples of an Alouatta primate, which died in Anastácio-MS, in 2008 (PM Baptist: unpublished data).

Yellow fever virus was also isolated from a sample of a non-human primate captured in an epidemic area in the State of Rio Grande do Sul (RS). Therefore, the Ministry of Health has standardized epidemic surveillance as part of its yellow fever (YF) surveillance strategy in order to identify feasible wild areas where YFV outbreaks might occur.

During the active surveillance for YF in RS, which occurred from 2002-2007, 181 non-human primates from several regions were caught and antibodies for OROV $(\mathrm{n}=1)$ and $\operatorname{SLEV}(\mathrm{n}=16)^{14}$ were detected using a neutralization test.

During an epizootic investigation on non-human primates in Bolivia, YFV was detected using RT-PCR ${ }^{15}$.

A study with 570 sera from Alouatta caraya from the Porto Primavera region, which is located in the Presidente Epitácio municipality in the State of São Paulo, reported negative results for immunoglobulin $\mathrm{G}(\mathrm{IgG})$ antibodies against YFV, a similar result to those observed in the City of Jardim, suggesting the absence of circulating YFV in this region. Moreover, no outbreak or human cases were detected ${ }^{16}$.

Some arboviruses, such as MAYV, SLEV, and NOV, are introduced in certain regions by migratory birds at certain times of the year, e.g., spring and summer, as they move to regions with favorable climatic conditions for reproduction. Consequently, people who have contact with enzootic foci are most at risk of acquiring infections ${ }^{17}$.

Aiming to detect YFV in non-human primates and transmitter vectors, sentinel animals were used in an epidemiological survey in Chaco and Corrientes provinces in northern Argentina. On that occasion, 4 SLEV serum samples were positive for the HI test. From these, 2 were confirmed by neutralization, suggesting the possible involvement of these primates in the natural life cycle of the virus. SLEV was also isolated in samples from humans, rodents, and arthropods in Argentina ${ }^{18}$. In another seroepidemiologic study with wild primates from the border of Paraná with the State of Mato Grosso do Sul, 123 primates were captured. From the serum samples obtained, 21 were seropositive for SLEV by the HI test ${ }^{6}$, suggesting the involvement of primates in the SLEV maintenance cycle in the Southern Cone region. SLEV was also detected in the State of Pará in Culex declarator and in migratory birds during epizootic cases observed in primates ${ }^{19}$, confirming the importance of these hosts in the disease cycle.

A serological survey in French Guiana on 150 sentinel primates detected high titers of antibodies for MAYV, suggesting the possible movement of this virus in the country. Serum samples from humans showed a high prevalence of antibodies to arboviruses ${ }^{20}$. The high levels of antibodies to MAYV found in the sera of animals trapped in the City of Bonito suggest the possible circulation of this virus in this location. MAYV antibodies were also found in Callithrix argentata primates by the $\mathrm{HI}$ test during an investigation of Mayaro and YF outbreaks in Belterra in the State of Pará ${ }^{19}$. 
The detection of antibodies against OROV in samples from primates in the city of Bonito, suggests the possible circulation of this virus in that region, which makes the local population and tourists who are in contact with the wild environment susceptible to OROV infection ${ }^{2}$.

The capture of Aedes serratus, considered one of the main vectors for OROV, in the city of Jardim suggests the possible transmission of this virus in this locality ${ }^{21}$. In Minas Gerais, during surveillance for YFV, OROV was isolated from a liver sample of a Callithrix primate ${ }^{22}$, which is considered a new host of OROV in Brazil.

Serological studies using ELISA in horses from Mato Grosso do Sul detected specific IgG antibodies to NOV and SLEV, suggesting intense virus activity in that state and indicating that horses can be used as sentinel animals to monitor arboviroses ${ }^{12}$. High titers of antibodies to SLEV were detected in horses from the City of Maracaju-MS using $\mathrm{HI}$ and neutralization tests ${ }^{23}$.

The diversity of the entomological species captured in the City of Jardim makes the population of this area susceptible to infection with arboviruses. In the Americas, the arthropod species Culex tarsalis, Culex pipiens, Culex quinquefasciatus, Culex declarator, and Culex coronator ${ }^{24}$ play an important role in the epizootic and enzootic cycles of SLEV ${ }^{19}$. The capture of the Culex genus in the City of Jardim makes the town vulnerable to infection by SLEV. Sabethes belisarioi has also been considered a potential SLEV vector since it was first isolated in Brazil in $1960^{22}$. In Brazil, along with Culex quinquefasciatus, Aedes scapularis and Aedes albopictus are considered important vectors for the transmission of this vírus ${ }^{25}$. Members of the genus Culex, especially the species Culex pipiens, are considered vectors of NOV in the United States ${ }^{26}$.

The migration of wild reservoir birds infected with NOV from the northern hemisphere to Brazil, coupled with favorable climatic conditions, ecosystem biodiversity, and an abundant population of Culex, makes the emergence of NOV possible in Brazil, especially in Mato Grosso do Sul. In 2006, NOV was isolated from samples taken from horses and humans in Argentina who had fever, headaches, and muscular aches ${ }^{27}$.

Psorophora ferox and Aedes scapularis mosquitoes captured in the City of Jardim were also suggested to be potential vectors for ROCV, as noted in the Atlantic forest areas in the southeastern State of São Paulo $^{28}$, which favors its reemergence. ROCV was isolated in humans in the southeast and in wild birds in southern Brazil, representing a continuing threat of outbreaks of severe encephalitis ${ }^{22}$.

Deforestation, disorganized urbanization, and other ecological changes promote an increase in the transmitter vector population, mainly the arthropod species Aedes aegypti and the Culex genus, which favors the emergence of arboviruses. Moreover, modern transport facilitates the movement and spread of transmitter arthropods throughout several countries, as observed with DENV, West Nile virus, and Chikungunya ${ }^{22}$, creating a potential for pandemics.

Because the State of Mato Grosso do Sul borders other countries in South America, such as Paraguay and Bolivia, where a variety of arbovirus species of primates and arthropods have been detected, it presents ideal conditions for outbreaks and epidemics caused by MAYV, OROV, and some Flavivirus species. Therefore, studies of this nature are extremely important, wherein antibody detection for arboviruses, viral isolation, and the identification of circulating transmitter vectors can generate information about the risk of infection to which these populations are exposed.

\section{ACKNOWLEDGMENTS}

The authors thank the Health State Secretariat of Mato Grosso do Sul for logistical support, permanent materials, and consumable materials for the execution of the fieldwork.

\section{CONFLICT OF INTEREST}

The authors declare that there is no conflict of interest.

\section{FINANCIAL SUPPORT}

Foundation to support Development of Education, Science and Technology of the State of Mato Grosso do Sul (FUNDECT).

\section{REFERENCES}

1. Vasconcelos PF. Yellow Fever. Rev Soc Bras Med Trop 2003; 36:275-293.

2. Vasconcelos PFC, Travassos-da-Rosa APA, Pinheiro FP, Rodrigues SG, Travassos-da-Rosa ES. Arboviroses. In: Cimerman S, Cimerman B, editors. Medicina tropical. São Paulo: Editora Atheneu; 2003. p. 363-386.

3. Dégallier N, Hervé JP, Travassos-da-Rosa APA, Vasconcelos PFC, Travassos-daRosa JFS, Sá-Filho GC. A ecologia dos arbovírus na Amazônia: pesquisas atuais e perspectiva. Rev Fundação Serviço de Saúde Pública 1989; 31:127-129.

4. Thoisy B, Gardon J, Salas RA, Morvan J, Kazanji M. Mayaro vírus in wild mammals, French Guiana. Emerg Infect Dis 2003; 9:1326-1329.

5. Wolfe ND, Escalante AA, Karesh WB, Kilbourn A, Spielman A, Lal AA. Wild primate populations in emerging infectious disease research: the missing link? Emerg Infect Dis 1998; 4:149-158.

6. Svoboda WK. Vigilância de epizootia em primatas não humanos como instrumento de monitoramento de arboviroses e outras viroses de Interesse em Saúde Pública. [Doctors Thesis]. [Londrina (PR)]: Universidade Estadual de Londrina; 2007. 135 p.

7. Rocha VJ, Aguiar LM, Ludwig G, Hilst CLS, Teixeira GM, Svoboda WK, et al. Techniques and trap models for capturing wild tufted capuchins. Am J Primatol 2007; 28:231-243.

8. Santos FGA, Salas ER, Marques JCB, Marques CC, Farias EMP. Cloridrato de tiletamina associado com cloridrato de zolazepam na tranquilização e anestesia de calitriquídeos (Mammalia, Primates). Arq Bras Med Vet e Zootec 1999; 51:539-545.

9. Ministério da Saúde. Manual de vigilância de epizootias em primatas não humanos. Brasília: Secretaria de Vigilância em Saúde; 2005.

10. Gubler DJ, Kunog, Sather GE. Mosquito cell cultures and specific monoclonal antibodies in surveillance for dengue viruses. Am J Trop Med Hyg 1984; 33:158-165.

11. Petersen LR, Roehrig JT. West nile Virus: A reemerging global pathogen. Rev Biomed 2001; 12:208-216.

12. Silva JR. Pesquisa de infecções por Flavivírus da encefalite de Saint Louis, Rocio e Oeste do Nilo em cavalos, por inquérito sorológico e isolamento viral. [Masters Thesis]. [Ribeirão Preto (SP)]: Faculdade de Medicina de Ribeirão Preto; $2010.62 \mathrm{p}$

13. Roig C, Rojas A, Guillén Y, Aria L, Mendonza L, Acosta ME, et al. Estudo de fiebre amarilla em primates em área de brote de los departamentos de San Pedro y Central de Paraguay. Mem Inst Investig Cienc Salud 2009; 7:40-45.

14. Almeida MAB, Santos E, Cardoso JC, Fonseca DF, Torres MAN, Cardoso LL, et al. Vigilância da febre amarela e outras arboviroses através do monitoramento de primatas não humanos de vida livre no Rio Grande do Sul. Rev Soc Bras Med Trop 2008; 41 (supl I):173.

15. Méndez JA, Parra É, Neira M, Rey GJ. Detección por reacción em cadena de La polimerasa de transcriptasa inversa del vírus de La fiebre amarilla em monos silvestres: uma herramienta sensible para La vigilância epidemiológica. Biomed 2007; 27:61-467. 
16. Lima MA, Lieber NSR, Duarte AMRC. Circulation of antibodies against yellow fever vírus in a siman population in the área of porto primavera hydroelectric plant, São Paulo, Brazil. Rev Inst Med Trop Sao Paulo 2010; 52:11-15.

17. Mclean RG, Scott TW. Avian hosts of St. Louis encephalitis virus [Internet]. Nebraska: University of Nebraska-Lincoln; 1979 [Cited 2010 Jul 23] Available from: http://digitalcommons.unl.edu/icwdmbirdcontrol/20/.

18. Bonttinelli O, Paz V, Enria D, Marta S, Gustavo S, Pedroni E. Infecciones por flavivirus y alphavirus em monos Alouatta caraya del Nordeste Argentino, año 2001 [Internet]. [Cited 2010 Sep 12] Available from: http://www1.unne.edu. ar/cyt/2002/04-Veterinarias/V-051.pdf.

19. Vasconcelos PFC, Travassos-da-Rosa JFS, Travassos-da-Rosa APA, Dégallier N, Pinheiro FP, Sá-Filho GC. Epidemiologia das encefalites por arbovírus na Amazônia brasileira. Rev Inst Med Trop São Paulo 1991; 33:465-476.

20. Talarmim A, Chandler LJ, Kaznji M, Thoisy B, Debon F, Lelarge J, et al. Mayaro virus fever in French Guiana:isolation, identification e seroprevalence. Am J Trop Med Hyg 1998; 59:452-456.

21. Vasconcelos PFC, Rosa APAT, Dégallier N, Rosa JFST, Pinheiro FP. Clinical and ecoepidemiological situation of human arboviruses in Brazilian Amazônia. Cienc Cult 1992; 44:117-124.

22. Figueiredo LTM. Arboviroses emergentes no Brasil. Rev Soc Bras Med Trop 2007; 40:224-229.

23. Rodrigues SG, Oliva OP, Araujo FAA, Martins LC, Chiang JO, Henriques DF, et al. Epidemiology of Saint Louis encephalitis virus in the Brazilian Amazon region and in the State of Mato Grosso do Sul, Brazil: elevated prevalence of antibodies in horses. Rev Pan Amaz 2010; 1:81-86.

24. Lavosei AL. Culicídeos (Mosquitos). In: Cimerman S, Cimerman B, editors. Medicina Tropical. São Paulo: Editora Atheneu; 2003. p. 59-102.

25. Natal D, Ueno HM. Vírus do Nilo Ocidental: característica da transmissão e implicações vetoras. Entomol Vect 2004; 11:417-433.

26. Turrel MJ, Dohm DJ, Sardelis MR, O'guinn ML, Andreadis TG, Blow JA. An update on the potential of North American mosquitoes (Diptera: Culicidae) to transmit West Nile Virus. J Med Entomol 2005; 42:57-62.

27. Morales MA, Barrandeguy M, Fabbri C, Garcia JB, Vissani A, Trono K, et al. West Nile virus isolation from equines in Argentina, 2006. Emerg Infect Dis 2006; 12:1559-1561.

28. Mitchell CJ, Forattini OP, Miller BR. Vector competence experiments with Rocio virus and three mosquito species from the epidemic zone in Brazil. Rev Saude Publica 1986; 20:171-177. 